\section{Audit opinion impact in the investors' perception - empirical evidence on Bucharest Stock Exchange}

\section{Tatiana DĂNESCU,}

"Petru Maior" University from Tîrgu Mureş,

E-mail: tatiana.danescu@gmail.com

Ovidiu SPĂTĂCEAN,

"Petru Maior" University from Tîrgu Mureş,

E-mail: ovidiu.spatacean@ea.upm.ro

\section{Alustract}

The integrity and credibility of financial statements are sensitive aspects that significantly influence the investors' confidence in the capital market efficiency. Recent research in the area of (re)establishing effective communication between the auditor and the investors have brought into the attention of audit practitioners the provisions of International Standard on Auditing (ISA) 701 "Communicating Key Audit Matters in the Independent Auditor's Report." This approach proves that investors demand more information that accompanies the audit opinion, when forming a decision to buy, hold or sell equity instruments. Our research is focused on identifying, isolating and analyzing the significant changes in financial asset trading prices, as a consequence of publishing the auditor report. Thus, the overall objective is to assess the impact of the modified opinion, expressed by the auditor in accordance with ISA 705 "Modifications to the Opinion in the Independent Auditor's Report", upon the prices of financial assets. Subsequently, the specific objectives aim to identify quantifiable adjustments in the financial position of the entities and to analyze its impact on trading prices. Research is focused on a sample that consists of 32 listed entities, of which 25 entities are included in the $B E T-X T$ index and seven entities are traded on the alternative trading system $A e R O$, selected in relation to the liquidity degree measured by the BVB market operator. Our observations upon changes in financial asset prices were focused on 2009-2017 period, while the analized audit reports addressed the reporting periods from 2008 to 2016, included.

Keywords: Audit opinion, misstatement, audit adjustments, financial statements' reliability, investors' perception

\section{JEL Classification: M42}

\section{To cite this article:}

Dănescu, T. and Spătăcean, O. (2018), Audit opinion impact in the investors' perception - empirical evidence on Bucharest

Stock Exchange, Audit Financiar, vol. XVI, no. 1(149)/2018, pp. 111-121, DOI: 10.20869/AUDITF/2018/149/003

To link to this article:

http://dx.doi.org/10.20869/AUDITF/2018/149/003

Received: 06.11.2017

Revised: 08.11.2017

Accepted: 09.11.2017 


\section{Research mothod}

The general objective of our research is to identify the significant variations associated with the movement of financial instruments' trading price, as a result of disseminating the audit report. A first research engagement was to observe the variation of the closing price in comparison with the 10 day average price, considering five days before and five days after the notice date of Ordinary General Meeting of Shareholders (AGOA) called for the approval of annual financial statements. The sample consisted of 32 listed entities, from which 25 entities from the BET-XT index, traded on the regulated market and seven entities traded on the AeRO alternative trading system, selected according to liquidity and stock market capitalization criteria. In order to form an opinion regarding the extent to which a significant price movement could be explained by the general market context, we determined the correlation coefficients with the change in the BET stock index. For the selected sample, we reviewed the audit reports published during 2009-2017, related to the reporting periods ended at December 31st 2008-2016.

Our interest aimed to identify modified audit reports (expressing an opinion other than unqualified) and to draw conclusions about the rational or irrational character associated with the investor's perception upon trading prices, as a result of releasing the audit reports. We consider the assumption of an irrational approach the circumstances when: (i) modified audit reports were issued and the price change at the issue date of these reports was positive and higher than $1 \%$ related to the 10 trading day average price, or (ii) unmodified audit reports were issued and the price change at the issue date of these reports was negative and higher than $1 \%$ related to the 10 trading day average price.

Exceptionally, we admit the possibility that a positive price movement might intervene including in the case of disseminating a modified opinion, in the absence of a quantifiable adjustment which may signal to investors a decrease in unitary net assets.

Another important research direction was focused towards the analysis of the modified audit reports, in order to identify relevant aspects that determined the change of the financial auditor's opinion, the impact in the entity's financial position and performance, as well as the type of audit adjustment. For the quantifiable audit adjustments, we reviewed the financial statements that were accompanied by the independent auditor's report in order to determine the expected adjustment in unitary net assets (equity per share) in correlation with the actual change in the trading price. Our attention has been drawn to the circumstances in which, although a reduction of net unitary assets would have been reasonably required, as a result of the audit adjustments pronounced by the independent financial auditor, in fact, trading prices recorded either a significant increase, or a significantly disproportionate correction. These circumstances could confirm the irrational nature of investors' perception relative to aspects communicated in the audit report.

\section{Financial statements' reliabillity in investors' perception}

The integrity of the capital markets is conditioned by the free access of investors to financial information that meets the qualitative, fundamental and amplifying requirements, as outlined in the general conceptual framework of financial reporting issued by the IASB in 2010. Good functioning of the capital markets is ensured only when accurate and reliable information is disseminated between stakeholders who have invested in the performance and financial perspectives of a listed entity. This information is designed to outline the economic profile of the business of such an entity and provides a basis for assessing progress in achieving long-term objectives. If the market does not receive high-accuracy information, the confidence in the system is seriously affected, and investors make poor quality decisions, registering losses (Rittenberg and Schwieger, 2005).

Disseminating reliable financial statements supports the user community in allocating resources in an efficient manner (Whittington and Pany, 2008). As regards a stock market, in order for the targeted users to obtain reliable information, it is necessary for the financial statements to undergo an independent audit. In this way, stakeholders will make decisions based on the audited information, assuming that they are, in a reasonable manner, complete, fair and unbiased (Arens, Elder and Beasley, 2008). In other words, the auditor's review of financial information adds credibility and reduces information risk, given the presumed conflict of interest that might exist between management and capital owners, from the perspective of information asymmetry 
theory. In this context, one can mention the case of former Enron's chief financial officer, who pleaded guilty to the charge of manipulating results in order to determine a rise in the price of the company's shares, followed by the receipt of consistent financial incentives and the sale of shares at an artificially increased price (Messier, Glover and Prawitt, 2008, p. 6-7).

The credibility of financial statements is the central issue for regulators, in their efforts to protect the public interest. This requirement strengthens the need for audit services and provides an active role for auditors in the context of capital markets. From this perspective, audit missions respond to informational valences, by improving the corporate reporting process and by reducing the possibilities for information to be presented erroneously or in a biased manner, thus contributing to the formation of investors' expectations (Soltani, 2007, p. 45,51$)$.

\section{The influence of misstatements related to financial statements unon price volatility}

Enron, HealthSouth, Kmart, Parmalat, Tyco, WorldCom, Waste Management, Sunbeam, Adelphia

Communications or Xerox represent just a few examples

of companies that were subject to profound debates regarding the dissemination of financial information departed from the regulatory requirements, with undesirable effects in the business community. As a result of the accounting fraud unrevealed within these corporations, investor confidence has been seriously shaken, which has led to the collapse of trading prices. According to sources in the relevant literature (Louwers et al., 2007, p. 2), financial experts have estimated investors' losses to USD 7 trillion, over a period of three years from peak prices recorded in September 2000. For example, Xerox Company has been accused of a variety of accounting manipulation techniques, applied between 1997 and 2000, in order to meet investors' expectations and to disguise the true dimensions of operational performance. According to allegations issued by the Securities Exchange Commission, the company has over-estimated revenues of more than USD 3 billion and pre-tax profits of USD 1.5 billion. The share price, which was above USD 60 per share before the announcement of accounting issues, fell to less than USD 5 per share after controversial accounting practices were revealed. Much more famous in American corporate history was Enron case. On November 8, 2001, the company announced an overestimation of the earnings declared over the last four years by USD 586 million, as well as the fact that it owed an estimated USD 3 billion due to past unreported liabilities. At the time of bankruptcy registration (December 2, 2001), the stock price fell to USD 0.40 per share, from maximum values that exceeded USD 100 per share (Beasley et al., 2009, p. $79,111,116)$. Another case that has been remarked by the magnitude that has hit investor confidence in the capital market was WorldCom. In June 2002, this company announced a rectification of its financial results caused by the capitalization over the most recent two reporting periods of USD 3.8 billion in expenses, although the amount would have impacted upon the accounting result. Thus, many investors made decisions based on information that did not accurately reflect the company's profitability. When the information was corrected, the trading price collapsed and investors lost billions of US dollars (Boynton and Johnson, 2006, p. 3, 16). In fact, at the time, the WorldCom scandal was perceived as "the largest accounting fraud in history, with an overstatement of revenue estimated at USD 11 billion, an overvalued balance sheet of over USD 75 billion, and shareholders' losses estimated at USD 200 billion USD" (Opinion and Order, SEC vs. WorldCom, Inc., United States District Court, Southern District of New York, July 7, 2003 (02 Civ. 49-63), cited by Ricchiute, 2006, p. 41).

Most frequently, the cause of distortions that appear in the financial statements relates to vulnerabilities in internal control over financial reporting. Some studies, centred on the assessment of the costs and benefits associated with internal control, under the SarbanesOxley Act, Section 404, reporting requirements have highlighted the fact that a strong internal control may result in an increase in trading prices. Thus, the Lord \& Benoit report (2006) (cited by Arens, Elder and Beasley, p.8) highlighted a $27.7 \%$ average increase in trading price between March 31, 2004 and March 31, 2006 for companies that did not report significant vulnerabilities in internal control over 2004 or 2005. In contrast, the share price declined on average by $5.7 \%$ for companies reporting vulnerabilities in internal control both in 2004 and 2005. It was also found that entities were "rewarded" for improvements in internal control. Thus, the average price increase was $25.7 \%$ for the 264 
companies that reported a material vulnerability in 2004, but which was eliminated in 2005 (Lord \& Benoit report, 2006). Other researchers (Kothari, Shu and Wysocki, 2009 , p. 273) have examined the extent to which management is delaying publication of negative news, as opposed to the publication of positive news. In their view, if management accumulates and delays the publication of negative news, within a materiality threshold, but quickly reveals positive news, even though leakage of private channel information, the magnitude of the negative change in the share price is expected to be higher than the one associated with a positive reaction if good news is published. Evidence of movements in trading prices suggested that, on average, management is delaying the dissemination of bad news to investors.

These insights into the literature supports the hypothesis that underlies our research, namely that the volatility of trading prices, as an expression of investors' perception upon financial statements, may be influenced by the auditor's opinion, particularly in the circumstances in which it is a modified one. The hypothesis is issued in the context of some results obtained from previous research conducted by the authors (Dănescu and Spătăcean, 2017), according to which the usage of different asset valuation basis may cause adjustments of financial performance, "with impact upon investors' perception and implicitly upon trading prices."

\section{Empirical resulits}

Investors' perception upon the financial assets' trading prices is influenced by a multitude of factors, both financial and psychological. One cannot identify exact delimitation between the two categories of factors; therefore our observations regarding the volatility of trading prices are subject to limitation in matter of isolating the impact associated with the dissemination of audit reports. We based our research on the assumption that investors' perception related to audit opinion may be faded by other factors with a more profound impact on trading prices, generally measured by the evolution of the stock market index. This may be the case, for example, when a high degree of correlation is established between the variation in the trading price of an issuer and the change in the stock index. In this approach, we have determined the values of the correlation coefficient between the variation of trading prices observed at the notice date of Ordinary General Meeting of Shareholders (AGOA) called for the approval of annual financial statements ${ }^{1}$ and the variation of BET index, during the period 2009-2017. In order to capture most of the effects on trading prices, the variation on AGOA notice date was determined in relation to the average closing prices over a period of 10 days, respectively 5 days before and 5 days after the publication of the current report regarding AGOA convocation. From the total of 32 listed entities selected in the sample, we were unable to determine the value of the correlation coefficient in case of 10 entities, either due to lack of relevance associated with a short trading period starting from the listing date (7 issuers) or due to extremely low liquidity on the AeRO market ( 3 issuers). The synthesis of the empirical results is presented in Table no. 1.

Based on the empirical data obtained, we concluded that for six issuers, the correlation coefficient values (less than -0.5) highlighted a medium-strong and indirect dependence between the change in trading price and the stock index variation. From the perspective of the defined research objectives, in such circumstances, we expect that the overall market evolution, measured by the stock index, does not affect the price movement. In other words, for these issuers there is a high probability that the price change to better capture investors' perception upon financial statements, including the audit report, if modified. This segment of issuers holds a weight of $27 \%$. On the opposite side, we observed values in case of two issuers (TBM and SIF3) for which the correlation coefficient values were positioned above 0.40 . For a number of three issuers, the correlation coefficient values placed in the range $(-0.35 ; 0)$ have highlighted

1 According to article $117^{2}$ from the Company Law no. 31/1990, republished, with subsequent modifications and completions, the annual financial statements [...] are made available to shareholders [...] at the GSM notice date. Provided that the approval of the annual financial statements is based on the reports presented by the Board of Directors, respectively the Directorate and the Supervision Board, including the financial auditor, we presume that the audit reports are published along with the annual financial statements, at the GSM notice date. Therefore, the GSM notice day represents the first time when investors have acces to the type of audit opinion expressed in the audit report that accompanies the annual financial statements published by an issuer. 
a low and indirect dependence, which indicates that investors' perceptions may be affected by the dissemination of financial statements, but in a smaller measure than in the case of a strong and indirect dependence. For most issuers in the sample
(11 entities, representing 50\%), the correlation coefficient values were positive but less than 0.40 without supporting an appreciation on the manner in which the disclosure of the financial statements could influence investors' perceptions upon the trading price.

\begin{tabular}{|c|c|c|}
\hline Industry & Issuer & Correlation coefficient \\
\hline \multirow{6}{*}{ Asset management } & Fondul Proprietatea & 0.19 \\
\hline & SIF Banat Crişana & -0.65 \\
\hline & SIF Moldova & -0.32 \\
\hline & SIF Transilvania & 0.71 \\
\hline & SIF Muntenia & 0.22 \\
\hline & SIF Oltenia & -0.22 \\
\hline Financial market management & Bursa de Valori București & -0.54 \\
\hline \multirow[t]{2}{*}{ Banking } & Banca Transilvania & -0.21 \\
\hline & BRD - Groupe Societe Generale & 0.28 \\
\hline Construction & Impact Developer Contractor & -0.72 \\
\hline \multirow{5}{*}{ Energetic } & OMV Petrom & 0.34 \\
\hline & SNTGN Transgaz & -0.54 \\
\hline & CNTEE Transelectrica & 0.21 \\
\hline & Conpet & 0.02 \\
\hline & Foraj Sonde Videle & -0.51 \\
\hline \multirow{7}{*}{ Manufacturing industry } & Teraplast & 0.39 \\
\hline & Compa & -0.56 \\
\hline & Vrancart & 0.18 \\
\hline & Iproeb Bistrița & 0.30 \\
\hline & IAR Brasov & 0.05 \\
\hline & Turbomecanica & 0.49 \\
\hline & Electroargeş & 0.30 \\
\hline
\end{tabular}

Source: Authors' projection

Another relevant research direction aimed to identify the circumstances in which investors' perception upon the credibility of financial statements is affected by other influences than those that imposed a modification in the audit opinion and which would have required an adjustment in the unitary net assets. These circumstances were highlighted by a positive and over-unitary (> 1\%) movement of the trading price in comparison with the ten-day average, under the circumstances of a modified audit report being published on the date when the variation was observed. The empirical results are summarized in Table no. 2.
Based on the conducted investigations, consisting of 230 observations upon price movement at the date of dissemination the current report regarding AGOA notice, over the period 2009-2017, we identified a total of 74 circumstances (32\%) in which the price change was positive and higher than $1 \%$, respectively 52 circumstances $(23 \%)$ in which the price change was negative and more than $1 \%$. Related to the daily stock market index evolution over the period 2009-2017, we determined that a $1 \%$ change in the trading price may be a material threshold in assessing investors' perception upon the dissemination of the financial statements and the financial independent auditor's report. 
Table no. 2: Price movement correlated with audit opinion type

\begin{tabular}{|l|c|l|l|}
\hline Positive and over-unitary price movement (\%) & 74 & $100 \%$ & Perception \\
\hline Circumstances in which an unqualified audit opinion was issued & 51 & $69 \%$ & Rational \\
\hline Circumstances in which a qualified audit opinion was issued & 18 & $24 \%$ & Irrational \\
\hline Circumstances in which a disclaimer of opinion was pronounced & 1 & $1 \%$ & Irrational \\
\hline Circumstances in which the audit report was not available & 4 & $5 \%$ & Unquantifiable \\
\hline Negative and over-unitary price movement (\%) & 52 & $100 \%$ & Perception \\
\hline Circumstances in which an unqualified audit opinion was issued & 38 & $73 \%$ & Irrational \\
\hline Circumstances in which a qualified audit opinion was issued & 9 & $17 \%$ & Rational \\
\hline Circumstances in which a disclaimer of opinion was pronounced & 0 & $0 \%$ & Rational \\
\hline Circumstances in which the audit report was not available & 5 & $10 \%$ & Unquantifiable \\
\hline Overall assessment & 126 & $100 \%$ & Perception \\
\hline Number of investigations & 60 & $48 \%$ & Rational \\
\hline Number of investigations & 57 & $45 \%$ & Irrational \\
\hline Number of investigations & 9 & $7 \%$ & Unquantifiable \\
\hline
\end{tabular}

Source: Authors' projection

Over the analyzed period, we examined a total of 217 audit reports published by the issuers selected in the sample. Among these audit reports, 176 reports (81\%) were unmodified audit reports (unqualified opinion), while 41 reports (19\%) were modified audit reports. Regarding the modified audit reports, we concluded that a single report expressed a "disclaimer of opinion", the rest of the reports containing qualified opinion. As a result of these findings, we are entitled to appreciate that the financial statements of the issuers selected in the sample reflect a high level of compliance with the requirements of the financial reporting framework, mainly IFRS. However, for the purposes of our research, we have shown interest in modified audit reports, from the perspective of the impact upon investors' perception, measured by the change in the trading price. Corroborating the nature of the price change (positive or negative) with the type of audit opinion, we determined that investors' perception related solely to the type of audit opinion, was irrational: (i) in 19 out of a total 74 cases, meaning that although the audit opinion was qualified, the price movement was positive and higher than 1\%; (ii) in 38 out of a total 52 cases, in the sense that although the audit opinion was clean, the price movement was negative and more than $1 \%$. For the purpose of our research, the second type of circumstances is irrelevant, as investors' perception could have been influenced by other factors associated with financial reporting, such as the release of financial statements reflecting a deterioration in financial performance and cash flows or the disclosure of disappointing perspectives for investors in terms of the issuer's intention and ability to distribute dividends. In summary, it can be concluded that, based exclusively on the type of audit opinion, the investors' perception upon the credibility of the financial statements was rational in $48 \%$ and irrational in $45 \%$ of the investigated circumstances. For a number of nine investigations, the audit report was not available, which did not allow the assessment of investors' perceptions.

After drawing some conclusions regarding the investors' perception about the credibility of financial statements, the analysis targeted the identification of circumstances that led to a modified audit opinion, as well as assessing the impact upon the financial position and performance, by investigating the audit adjustments expressed in the modified audit reports. From the sample subject to our tests, we identified a number of 11 issuers for which we reviewed the modified audit reports to determine possible quantifiable audit adjustments that could have influenced investors' perceptions upon trading prices, at the time when audit reports were released. The results of our investigations are presented in Table no. 3. 


\begin{tabular}{|c|c|c|c|c|c|c|}
\hline $\begin{array}{l}\text { Issuer } \\
\text { symbol }\end{array}$ & $\begin{array}{l}\text { Observation } \\
\text { date }\end{array}$ & $\begin{array}{l}\text { Price } \\
\text { change } \\
(\%)\end{array}$ & $\begin{array}{c}\text { BET } \\
\text { change(\%) }\end{array}$ & Basis for modified opinion & $\begin{array}{c}\text { Impact in position and } \\
\text { financial } \\
\text { performance }\end{array}$ & $\begin{array}{l}\text { Type of audit } \\
\text { adjustment }\end{array}$ \\
\hline EL & 31.03 .2015 & 1.46 & 0.13 & $\begin{array}{l}\text { Lack of sufficient and } \\
\text { adequate audit evidence } \\
\text { related to investments in } \\
\text { other entities. }\end{array}$ & $\begin{array}{l}\text { Overstatement of } \\
\text { financial investments, } \\
\text { current period result, } \\
\text { retained earnings and } \\
\text { reserves. }\end{array}$ & $\begin{array}{l}\text { Unquantifiable. } \\
\text { The impact } \\
\text { upon net } \\
\text { assets cannot } \\
\text { be measured. }\end{array}$ \\
\hline \multirow[t]{5}{*}{ TEL } & 27.03 .2014 & 2.31 & 0.26 & \multirow{5}{*}{$\begin{array}{l}\text { Incorrect classification of } \\
\text { non-current liabilities as a } \\
\text { result of non-fulfillment of } \\
\text { some financial indicators. }\end{array}$} & \multirow{5}{*}{$\begin{array}{l}\text { Understatement of } \\
\text { current debts. }\end{array}$} & \multirow{5}{*}{$\begin{array}{l}\text { Quantifiable. } \\
\text { No impact } \\
\text { upon net } \\
\text { assets. }\end{array}$} \\
\hline & 25.03 .2013 & 1.23 & 0.16 & & & \\
\hline & 22.03 .2012 & 1.29 & -0.75 & & & \\
\hline & 26.03 .2010 & 2.12 & 0.16 & & & \\
\hline & 26.03 .2009 & 2.42 & 3.58 & & & \\
\hline \multirow[t]{2}{*}{ SNN } & 26.03 .2015 & 1.27 & 0.18 & \multirow[b]{2}{*}{$\begin{array}{l}\text { Lack of sufficient and } \\
\text { adequate audit evidence } \\
\text { about the allocation of the } \\
\text { tangible assets' carrying } \\
\text { amount. }\end{array}$} & \multirow[b]{2}{*}{$\begin{array}{l}\text { Overstatement of } \\
\text { fixed assets, current } \\
\text { period result and } \\
\text { retained earnings. } \\
\text { Understatement of } \\
\text { debt related to } \\
\text { deferred income tax. }\end{array}$} & \multirow{2}{*}{$\begin{array}{l}\text { Unquantifiable. } \\
\text { The impact } \\
\text { upon net } \\
\text { assets cannot } \\
\text { be measured. }\end{array}$} \\
\hline & 27.03 .2014 & 1.89 & 0.26 & & & \\
\hline FOJE & 13.04 .2017 & 9.19 & 0.49 & $\begin{array}{l}\text { Signs of impairment related } \\
\text { to interests in other entities. }\end{array}$ & $\begin{array}{l}\text { Overstatement of } \\
\text { financial investments } \\
\text { and current period } \\
\text { result. }\end{array}$ & $\begin{array}{l}\text { Unquantifiable. } \\
\text { The impact } \\
\text { upon net } \\
\text { assets cannot } \\
\text { be measured. }\end{array}$ \\
\hline SIF3 & 28.02 .2014 & 5.49 & 0.96 & $\begin{array}{l}\text { Lack of sufficient and } \\
\text { adequate audit evidence } \\
\text { about the recoverable } \\
\text { amount of certain financial } \\
\text { assets. }\end{array}$ & $\begin{array}{l}\text { Overstatement of } \\
\text { financial investments, } \\
\text { global result and } \\
\text { reserves. } \\
\text { J Understatement of } \\
\text { debt related to } \\
\text { deferred income tax. }\end{array}$ & $\begin{array}{l}\text { Unquantifiable. } \\
\text { The impact } \\
\text { upon net } \\
\text { assets cannot } \\
\text { be measured. }\end{array}$ \\
\hline TRP & 29.03 .2011 & 1.83 & -1.02 & $\begin{array}{l}\text { Exceptions found in the } \\
\text { process of external } \\
\text { confirmation related to } \\
\text { receivables. }\end{array}$ & $\begin{array}{l}\text { Overstatement of } \\
\text { receivables and } \\
\text { current period result. }\end{array}$ & $\begin{array}{l}\text { Quantifiable. } \\
\text { The unitary } \\
\text { value of net } \\
\text { assets should } \\
\text { decrease by } \\
0.94 \% \text {. }\end{array}$ \\
\hline VNC & 21.03 .2014 & 6.43 & -0.83 & $\begin{array}{l}\text { Lack of sufficient and } \\
\text { adequate audit evidence } \\
\text { regarding inventory } \\
\text { quantities. Misstatements in } \\
\text { fair value measurements } \\
\text { (revaluation model) of fixed } \\
\text { assets. }\end{array}$ & $\begin{array}{l}\text { Overstatement of } \\
\text { inventories and } \\
\text { tangible assets, } \\
\text { revaluation reserves, } \\
\text { current period result } \\
\text { and retained earnings. }\end{array}$ & $\begin{array}{l}\text { Unquantifiable } \\
\text { (inventory). } \\
\text { Quantifiable } \\
\text { (fixed assets). } \\
\text { The unitary } \\
\text { value of net } \\
\text { assets should } \\
\text { decrease by } \\
4.42 \% \text {. }\end{array}$ \\
\hline
\end{tabular}




\begin{tabular}{|c|c|c|c|c|c|c|}
\hline $\begin{array}{l}\text { Issuer } \\
\text { symbol }\end{array}$ & $\begin{array}{l}\text { Observation } \\
\text { date }\end{array}$ & $\begin{array}{l}\text { Price } \\
\text { change } \\
(\%)\end{array}$ & $\begin{array}{c}\text { BET } \\
\text { change(\%) }\end{array}$ & Basis for modified opinion & $\begin{array}{c}\text { Impact in position and } \\
\text { financial } \\
\text { performance }\end{array}$ & $\begin{array}{l}\text { Type of audit } \\
\text { adjustment }\end{array}$ \\
\hline \multirow[t]{2}{*}{ TBM } & 25.03 .2015 & 1.58 & -0.03 & \multirow[b]{2}{*}{$\begin{array}{l}\text { Lack of sufficient and } \\
\text { adequate audit evidence } \\
\text { about the recoverable } \\
\text { amount of inventories; } \\
\text { Selective treatment in asset } \\
\text { revaluation; Significant } \\
\text { uncertainties about } \\
\text { business continuity. }\end{array}$} & \multirow[b]{2}{*}{$\begin{array}{l}\text { Overstatement of } \\
\text { inventories and } \\
\text { tangible assets, } \\
\text { revaluation reserves, } \\
\text { current period result } \\
\text { and retained earnings. }\end{array}$} & \multirow{2}{*}{$\begin{array}{l}\text { Unquantifiable. } \\
\text { The impact } \\
\text { upon net } \\
\text { assets cannot } \\
\text { be measured. }\end{array}$} \\
\hline & 24.03 .2014 & 2.11 & 0.44 & & & \\
\hline ELGS & 20.03 .2015 & 2.77 & -0.66 & $\begin{array}{l}\text { Lack of adjusting certain } \\
\text { equity items to inflation; } \\
\text { Inconsistent application of } \\
\text { consolidation methods. }\end{array}$ & $\begin{array}{l}\text { Understatement of } \\
\text { equity. }\end{array}$ & $\begin{array}{l}\text { Unquantifiable. } \\
\text { The impact } \\
\text { upon net } \\
\text { assets cannot } \\
\text { be measured. }\end{array}$ \\
\hline TRVM & 29.03 .2016 & 39.36 & -0.60 & $\begin{array}{l}\text { Lack of sufficient and } \\
\text { adequate audit evidence } \\
\text { about the recoverable } \\
\text { amount of inventories. }\end{array}$ & $\begin{array}{l}\text { Overstatement of } \\
\text { inventories and current } \\
\text { period result. }\end{array}$ & $\begin{array}{l}\text { Unquantifiable. } \\
\text { The impact } \\
\text { upon net } \\
\text { assets cannot } \\
\text { be measured. }\end{array}$ \\
\hline \multirow[t]{3}{*}{ IMP } & 20.03 .2013 & 1.38 & 0.26 & $\begin{array}{l}\text { Lack of lawyer } \\
\text { confirmations regarding } \\
\text { litigation; Depreciated } \\
\text { inventories of finished } \\
\text { goods. }\end{array}$ & $\begin{array}{l}\text { Overstatement of } \\
\text { inventories and current } \\
\text { period result. } \\
\text { Understatement of } \\
\text { litigation provisions. }\end{array}$ & $\begin{array}{l}\text { Unquantifiable. } \\
\text { The impact } \\
\text { upon net } \\
\text { assets cannot } \\
\text { be measured. }\end{array}$ \\
\hline & 19.03 .2010 & 3.09 & -0.45 & $\begin{array}{l}\text { Lack of sufficient and } \\
\text { adequate audit evidence } \\
\text { regarding debts to local } \\
\text { budgets and commercial } \\
\text { debts. }\end{array}$ & $\begin{array}{l}\text { Understatement of } \\
\text { tax and commercial } \\
\text { debts. }\end{array}$ & $\begin{array}{l}\text { Unquantifiable. } \\
\text { The impact } \\
\text { upon net } \\
\text { assets cannot } \\
\text { be measured. }\end{array}$ \\
\hline & 27.03 .2009 & 8.47 & -3.55 & $\begin{array}{l}\text { Receivables not adjusted } \\
\text { for impairment; } \\
\text { Unrecognized commission } \\
\text { expense owed for pre-sale } \\
\text { commitments. }\end{array}$ & $\begin{array}{l}\text { Overstatement of } \\
\text { trade receivables and } \\
\text { current period result. }\end{array}$ & $\begin{array}{l}\text { Quantifiable. } \\
\text { The unitary } \\
\text { value of net } \\
\text { assets should } \\
\text { decrease by } \\
0.66 \% \text {. }\end{array}$ \\
\hline
\end{tabular}

Source: Authors' projection

As shown in Table no. 3, in most cases, the modification of the audit opinion was imposed by the lack of sufficient and adequate audit evidence regarding the recognition and valuation of certain assets, such as interests, investments in other entities and other financial assets; tangible assets measured at fair value; inventories or receivables. In financial auditors' opinion, these assets could have been overstated, in the absence of appropriate impairment tests and the recognition of appropriate adjustments.
According to facts presented by auditors in the audit reports, the identified misstatements could have a significant impact upon the position and financial performance of issuers, in the sense of overstating assets, equity and the current period result. In this approach, investors should appeal for a measure of circumspection in assessing fair value associated with tradable financial instruments.

Other circumstances that imposed modifications of the audit opinion were: identification of exceptions in the external confirmation process of receivables; lack of 
external confirmations from lawyers regarding litigation; significant uncertainties regarding going on concern assumptions or erroneous classification of long-term liabilities under the perspective of non-compliance with certain financial indicator requirements. Usually, these circumstances cannot be associated with quantifiable adjustments in unitary net asset value, in the absence of quantitative disclosures in the financial audit report.

As a result of our research conducted upon a number of 217 audit reports, we found a reduced number of circumstances in which investors could have been able to determine reductions in the unitary net asset value, based on quantifiable audit adjustments. To justify this statement, we affirm that from a total of 35 investigations conducted for the modified audit reports, quantifiable audit adjustments were identified in only 13 cases $(37 \%)$. Moreover, in eight of these cases, where the audit adjustments were quantifiable, there was no real impact upon the issuer's equity, since the misstatements were associated with some erroneous classifications of current liabilities. These conclusions could explain, to a certain extent, the irrational perception of investors about the credibility of the financial statements, namely that according to which, although a modified opinion was issued, the trading price at the moment of releasing the audit report recorded positive variations, significantly higher than the stock index variation. We exemplify in this context, the case of Foraj Sonde Videle (13.04.2017) and SIF Transilvania (28.02.2014). Moreover, in case of issuers such as Vrancart (21.03.2014), Transcom Bucharest (29.03.2016) or Impact Developer Contractor (27.03.2009), the movement in trading price was positive and unusually high (over 6\%), while the stock index recorded reductions.

As presented above, from a total number of 35 examinations regarding the modified audit reports, quantifiable audit adjustments were identified in only five cases (14\%), meaning that an expected reduction in the unitary value of the net assets could have been determined in a reasonable manner. The quantitative presentations are conveyed by Table no. 4 .

\begin{tabular}{|c|c|c|c|c|c|c|c|}
\hline \multirow[b]{2}{*}{$\begin{array}{l}\text { Issuer } \\
\text { symbol }\end{array}$} & \multirow{2}{*}{$\begin{array}{c}\text { Financial } \\
\text { Statement } \\
\text { Date }\end{array}$} & \multirow[b]{2}{*}{$\begin{array}{l}\text { Unadjusted } \\
\text { equity (lei) }\end{array}$} & \multirow{2}{*}{$\begin{array}{l}\text { Audit } \\
\text { adjustment } \\
\text { (lei) }\end{array}$} & \multicolumn{2}{|c|}{ Accounting value / share } & \multirow{2}{*}{$\begin{array}{l}\text { Expected } \\
\text { variation } \\
(\%)\end{array}$} & \multirow{2}{*}{$\begin{array}{c}\text { Actual } \\
\text { price } \\
\text { change } \\
(\%)\end{array}$} \\
\hline & & & & $\begin{array}{l}\text { Unadjusted } \\
\text { (lei/share) }\end{array}$ & $\begin{array}{c}\text { Adjusted } \\
\text { (lei/share) }\end{array}$ & & \\
\hline IMP & 31.12 .2011 & $296,828,111$ & $17,036,601$ & 1.5001 & 1.4140 & -5.74 & -1.05 \\
\hline IMP & 31.12 .2008 & $333,576,000$ & $2,191,860$ & 0.1668 & 0.1657 & -0.66 & 8.47 \\
\hline TRP & 31.12 .2010 & $152,076,691$ & $1,422,000$ & 0.5105 & 0.5058 & $\begin{array}{l}-0.94 \\
\end{array}$ & 1.83 \\
\hline VNC & 31.12 .2013 & $108,525,916$ & $4,800,000$ & 0.1256 & 0.1201 & -4.42 & 6.43 \\
\hline SIF1 & 31.12 .2008 & $413,631,925$ & $25,812,257$ & 0.7536 & 0.7066 & $\begin{array}{l}-6.24 \\
\end{array}$ & -0.69 \\
\hline
\end{tabular}

Source: Authors' projection

Our investigations were based on the assumption that a modified opinion expressed in the circumstances of an overstated financial position and performance, should determine, in a rational approach, the appropriate adjustment of unitary net assets. To capture these corrections, we determined the accounting value per share, as a ratio between the value of equity and the number of issued and tradable shares. These corrections, also referred to as expected variations, were confronted with the actual change in trading price related to the ten-day average. Analyzing the obtained results we can appreciate that investors were not influenced by the modified opinion expressed by the financial auditors, in their decision-making process. We exemplify the case of Vrancart issuer, which came forward with an increase in the trading price of $6.43 \%(21.03 .2014)$, while the audit adjustment identified in the auditor's report would have required a decrease of $4.42 \%$ in unitary net assets. Also, for the issuer SIF Banat Crişana the expected change in the unitary value of net assets was accounted for (-) $6.24 \%$ while the price change was significantly much lower, respectively (-) $0.69 \%$. In case of issuer Impact Developer Contractor we identified two situations in which the investors' reaction to the publication of the audit report was not the one to support the rational assumption. Thus, (i) on March 27, 2009 the trading 
price was higher by $8.47 \%$ compared to the ten-day average, while the BET index variation registered (-) $3.55 \%$ and the expected change in the unitary value of net assets was (-) 0.66\%; and (ii) on March 21, 2012 the expected variation in unitary value of net assets was (-) $5.74 \%$ while price movement versus ten-day average was significantly disproportionate, respectively (-) $1.05 \%$.

\section{Bonclusions and nersnectives}

The primary objective that governed our research was to evaluate the consequences of publishing a modified audit opinion upon investors' perception regarding the credibility of financial statements, from the perspective of the impact measured by the changes in trading prices. Our research was carried out on a sample of 32 entities listed on the Bucharest Stock Exchange, for financial statements disseminated over the period 2009-2017. The auditor's opinions expressed by the financial auditors were analyzed in correlation with changes in the trading prices, at each date the audit reports were published. Our main concern was to identify anomalies in trading price movements, when the audit reports contained modified opinion and when possible adjustments in the unitary value of net assets could have been quantified. The summary of findings supported by our research is described below.

An isolation of the influence that publication of audit reports might have on trading prices is difficult to achieve. In this regard, it should be specified that a limitation of our studies is the non-use of questionnaires in relation with investors. The use of this investigative tool could add value in quantifying investors' perception about the credibility of financial statements, by analyzing audit reports. This direction is emerging as a future research perspective. Related to the type of audit opinion examined, we determined a high level of issuer compliance with the requirements of the financial reporting framework. This assertion is supported by the fact that only $19 \%$ of the audit reports examined have expressed a modified opinion. In the context of observing price movements, strictly depending on the type of audit opinion, we estimate that investors' perception upon the credibility of the financial statements was irrational in $45 \%$ of the investigated cases. This finding can be argued by a small number of situations (14\%) in which the audit adjustments could have influenced investors' expectations regarding the change in unitary value of net assets. In this context, based on empirical evidence obtained from our research, we appreciate that investors considered, in a general approach, on a reduced scale the impact of modified opinion, in comparison with other matters, when they based their investment decisions. However, recent developments in matter of issuance an audit report for public interest entities could generate additional information value to investors, by describing key audit matters. This research hypothesis outlines another research perspective that we are considering for future research.

\section{REFERENCES}

1. Arens, A.A., Elder, R.J. and Beasley, M.S. (2008), Auditing and assurance services. An integrated approach, Twelfth edition, New Jersey, Pearson Prentice Hall.

2. Beasley, M.S., Buckless, F.A., Glover, S.M. and Prawitt, D.F. (2009), Auditing cases. An interactive learning approach, Fourth edition, New Jersey, Prentice Hall.

3. Boynton, W.C. and Johnson, R.N. (2006), Modern auditing. Assurance services and the integrity of financial reporting, Eighth edition, John Wiley \& Sons.
4. Dănescu T. and Spătăcean O. (2014), Controversies in auditing fair value accounting estimates for financial assets, Audit Financiar, vol. XII, no. 117(9), pp. 30-42.

5. Kothari, S.P., Shu, S. and Wysocki, P.D. (2009), Do managers withhold bad news?, Journal of Accounting Research, vol. 47, no. 1, pp. 241-276, DOI 10.1111/j.1475-679x.2008.00318.x .

6. Legea Societăților nr. 31/1990, republicată, cu modificările şi completările ulterioare, disponibilă la https://legeaz.net/legea-31-1990/, accessed on 1 November 2017. 
7. Louwers, T.J., Ramsay, R.J., Sinason, D.H. and Strawser, J.R. (2007), Auditing and assurance services, Second edition, New York, McGraw-Hill Irwin.

8. Messier, W.F., Glover, S.M. and Prawitt, D.F. (2008), Auditing and assurance services. A systematic approach, 5th edition, New York, McGraw-Hill Irwin.

9. Ricchiute, D.N. (2006), Auditing, $8^{\text {th }}$ edition, Thomson South-Western.
10. Rittenberg, L.E. and Schwieger, B.J. (2005), Auditing. Concepts for a changing environment, Fifth edition, Ohio, Thomson South-Western.

11. Soltani, B. (2007), Auditing. An international approach, Harlow, Essex, Pearson Education.

12. Whittington, O.R. and Pany, K. (2008), Principles of auditing \& other assurance services, $16^{\text {th }}$ edition, New York, McGraw-Hill Irwin.

13. www.bvb.ro 